\title{
Typification of Vulpia attenuata (Poaceae)
}

\author{
Clive A. Stace \\ Middlewood Green, Suffolk, U.K.
}

Corresponding author: cstace@btinternet.com

This pdf constitutes the Version of Record published on $16^{\text {th }}$ September 2021

\begin{abstract}
The various interpretations of Vulpia attenuata Parl. are outlined. The species is lectotypified on a Sicilian specimen of V. geniculata (L.) Link in FI.
\end{abstract}

Keywords: Vulpia geniculata, Vulpia sicula, Parlatore, FI herbarium

\section{Introduction}

Although all Vulpia species in central and northern Europe are annuals, with 1-3 cleistogamous or slightly exserted anthers up to $2 \mathrm{~mm}$ long, both perennial species and those with three long-exserted anthers more than $2 \mathrm{~mm}$ long occur in the Mediterranean basin. The commonest of the latter in the Iberian Peninsula and North Africa is the annual $V$. geniculata (L.) Link. This species extends in Europe to Mediterranean France and Italy but is much rarer there and very scattered in Italy (including Sardinia and Sicily), where the related annual V. ligustica (All.) Link is much commoner. A third apparently related (i.e. morphologically similar) species that occurs in Mediterranean France and Italy is the perennial chasmogamous $V$. sicula (C. Presl) Link. All three species occur in North Africa.

\section{Variation in Vulpia geniculata}

Vulpia geniculata is variable in Spain, where var. longig/umis Caball. is often recognized (Rodriguez \& Devesa, 2020), but is much more variable in North Africa (Morocco to Tunisia). Four extra subspecies were recognised there by Maire (1955) and by Dobignard \& Chatelain (2010): subspp. attenuata (Parl.) Trab., pauana (Font Quer) Maire, monanthera (Maire) Maire and brevig/umis (Trab.) Maire. Only subspp. geniculata and attenuata also occur in Europe. The first two in the above list were originally described as species, but more work in North Africa is required before their value can be assessed adequately. The most distinctive is subsp. pauana, which is distinguished by its short stature, dense, contracted panicle and short pedicels and lemma awns. According to Maire (1955), subsp. attenuata has a narrower panicle, narrower glumes and lemma, and a longer awn on the upper glume than subsp. geniculata. The above epithets longig/umis and brevig/umis refer to the upper glume surpassing or falling short of the adjacent (second) lemma.

\section{Identity of Vulpia attenuata}

Parlatore (1844) described "Vulpia attenuata nob." and stated that it occurred in Sicily "in campi marittimi vicino Palermo a Mondello". Despite Parlatore's provision of 
a long description, and detailed comparisons with both $V$. geniculata and $V$. setacea Parl. (V. sicula var. setacea (Parl.) Hack.), V. attenuata has not subsequently been accepted at species level, but has been placed under one or other of three species, including the above two. Fiori (Fiori \& Paoletti, 1896) reduced it to V. geniculata var. attenuata (Parl.) Fiori, and Trabut (Battandier \& Trabut, 1895) treated it as $V$. geniculata subsp. attenuata (Parl.) Trab. Similarly, Maire (1955), in his monumental Flore de l'Afrique du Nord, presented attenuata as one of five subspecies of $V$. geniculata (see above), and the same treatment is maintained in Dobignard \& Chatelain's Index Synonymique of the North African flora (2010), in the catalogue of Sicilian plants by Giardina et al. (2007, p. 455), and (as at April 2021) in the Euro+Med Plantbase. In The Plant List (version 1.1, 2013), however, V. attenuata is treated as a synonym of $V$. sicula, and the same is true in the latest Italian checklist (Bartolucci et al., 2018), and in The World Checklist of Selected Plant Families (as at January 2021). Finally, Pignatti (2017), in the second edition of Flora d'Italia, placed V. attenuata as a synonym of Vulpiella tenuis (Tineo) Kerguélen, a much more distantly related taxon which has several characters diverging widely from those of $V$. attenuata. In the first edition (Pignatti, 1982) it had appeared under $V$. geniculata.

Gussone (1845) recombined Parlatore's plant as Festuca attenuata (Parl.) Guss. shortly after Parlatore's publication, referring to it and giving the same localities in Sicily.

\section{Typification of Vulpia attenuata}

In the protologue of $V$. attenuata, in addition to citing the Sicilian localities above, Parlatore (1844) stated under geographical distribution that it had also been found in Sardinia by Prof. G.G. Moris, who (Parlatore claimed) confused it with (i.e. identified it as) Festuca sicula.

The correct attribution of $V$. attenuata obviously depends on its typification. Dr Chiara Nepi, Head Curator at Museo di Storia Naturale, Firenze (FI), has kindly provided me with high resolution images of the two type sheets. One (FI007024, Fig. 1) has two specimens: the one on the left is V. ciliata Dumort., as determined by $\mathrm{P}$. Auquier in 1978; the one on the right is V. geniculata, as determined by $\mathrm{E}$. Banfi in 1984. Both are covered by one label in Parlatore's handwriting, with the locality "in arenosis maritimis Mondello". The other sheet (FI007023, Fig. 2) also has two specimens. The one on the right is V. ligustica (no locality); a label on the sheet with that determination by P. Auquier (Liège) in 1978 probably refers to that specimen, although that is not clearly indicated. The one on the left is V. sicula; it was collected by Moris in Sardinia and is labelled by him Festuca sicula, with Vulpia attenuata added by Parlatore (hand-writing attributed by Chiara Nepi).

Hence there are two syntypes, both good representative specimens: Parlatore's from Sicily and Moris's from Sardinia, either of which could be chosen as lectotype since they both have label data clearly referred to in the protologue.

My choice of the specimen of $V$. geniculata as lectotype is based on: (1) certain characters stated by Parlatore, particularly the annual habit and the erect, nonsecund panicle, which ally it to V. geniculata rather than to V. sicula; (2) the listing by Parlatore, under 'Observations', of more differences from $V$. sicula than from $V$. geniculata; and (3) the treatment of $V$. attenuata under $V$. geniculata by the majority of previous Italian and North African botanists. It remains the case, 
however, that the majority of Italian and North African specimens that I have seen labelled $V$. geniculata subsp. attenuata are $V$. sicula. The main character mentioned by Parlatore that could suggest $V$. sicula is the pedicels thickened at the apex, but by no means ensiform ("apice incrassati, haud ensiformes"), whereas in $V$. geniculata they are usually ensiform (flattened and conspicuously thickened at the apex). The annual versus perennial habit might be thought of as unequivocal evidence either way, but in fact tillers are often rather few in V. sicula and it is easy to gather a specimen without any. The description of the lemma as 5-veined with obsolete laterals rules out Vulpiella as its possible identity.

Vulpia attenuata Parl., Giorn. Bot. Ital. 1(2): 349 (1844)

Lectotype (selected here): Sheet FI007024 (Fig. 1), right hand specimen, Sicilia, in arenosis maritimis Mondello, coll. Parlatore (= V. geniculata (L.) Link) (FI).

\section{Acknowledgements}

I am indebted to Chiara Nepi (Firenze) for valuable advice on the Italian literature, for much help in interpreting the type sheets of Vulpia attenuata in FI, and for obtaining permission for their reproduction in this paper. I am also grateful to Salvatore Brullo (Catania), Eckhard Raab-Straube (Berlin) and Kanchi Gandhi (Harvard) for helpful correspondence.

\section{References}

Bartolucci, F. et al. 2018. An updated checklist of the vascular flora native to Italy. Plant Biosystems 152: 179-303.

Battandier, J.A. \& Trabut, L.C. 1895. Flore de l'Algérie, 2. Monocotylédones. Algiers \& Paris: F. Savy.

Dobignard, A. \& Chatelain, C. 2010. Index Synonymique de la Flore de l'Afrique du Nord, 1. Genève: Conservatoire et jardin botaniques.

Euro+Med Plantbase. Available at: https://www.emplantbase.org/home.html

Fiori, A. \& Paoletti, G. 1896. Flora Analitica d'Italia, 1. Padova: Tipografia del Seminario.

Giardina, G., Raimondo, F.M. \& Spadaro, V. 2007. A catalogue of plants growing in Sicily. Bocconea 20: 5-582

Gussone, G. 1845. Florae Siculae Synopsis Exhibens Plantas Vasculares in Sicilia Insulisque Adjacentibus huc asque Detectas, Secundum Systema Linneanum Dispositas. Napoli: Tramater.

Maire, R.C.J.E. 1955. Gramineae. In Flore de l'Afrique du Nord, 3. Paris: P. Lechevalier.

Parlatore, F. 1844. Flora Palermitana ossia descrizione delle piante che crescono spontanee nella valle di Palermo. Giornale Botanico Italiano 1(2): 284-375.

Pignatti, S. 1982. Flora d'Italia. Bologna: Edagricole.

Pignatti, S. 2017. Flora d'Italia e flora digitale, ed. 2, 1. Bologna: Edagricole.

Rodriguez, A.M. \& Devesa, J.A. 2020. Vulpia C.C. Gmel., pp. 391-412. In:

Castroviejo, S. et al., eds. Flora Iberica, 19(1). Madrid: Real Jardín Botánico.

The Plant List. http://www.theplantlist.org

World Checklist of Selected Plant Families. Available at:

https://wcsp.science.kew.org/advsearch.do 


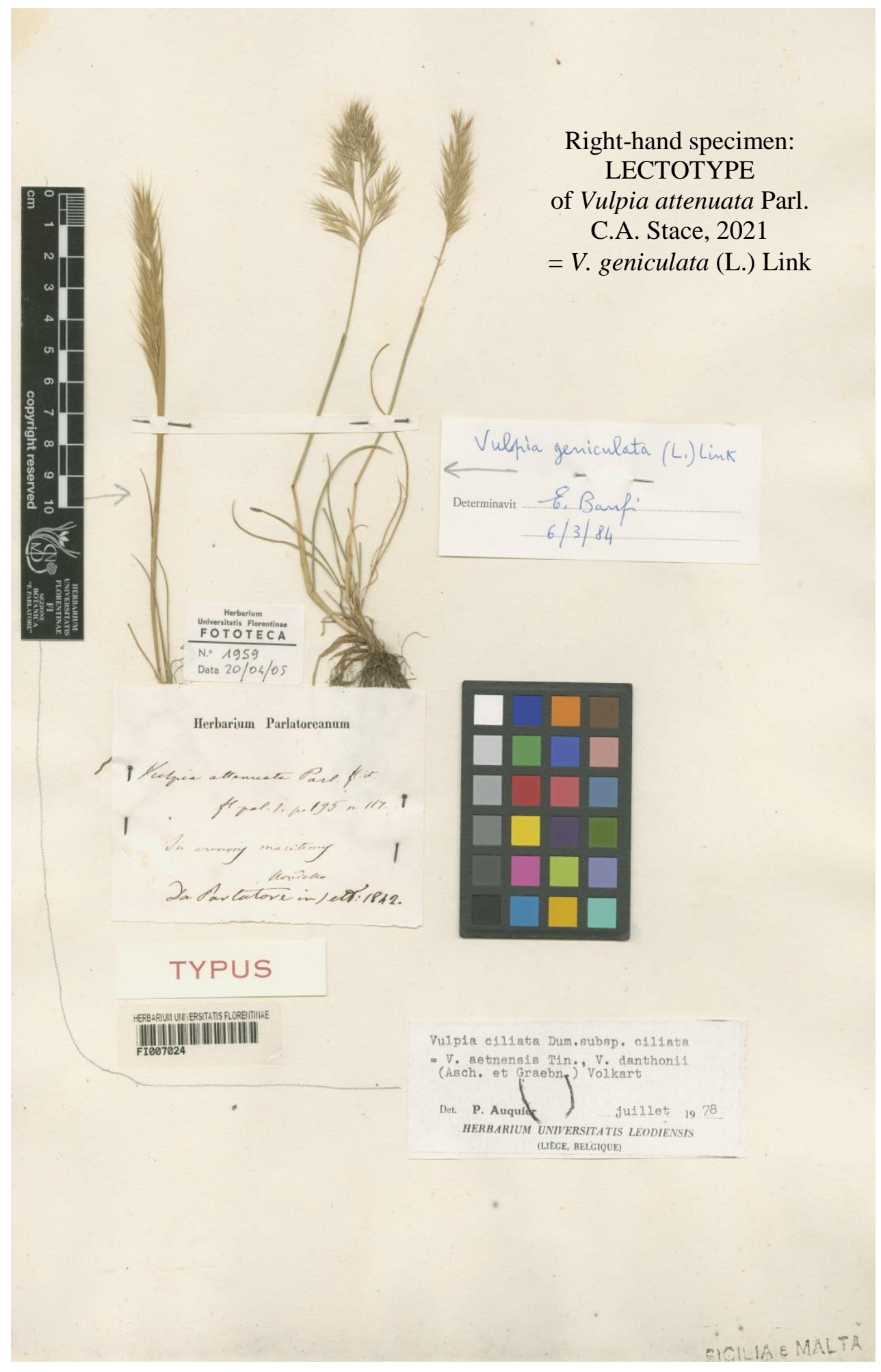

Figure 1. Sheet FI1007024. Right-hand specimen is the lectotype of Vulpia attenuata Parl., selected here, collected by F. Parlatore from Mondello, Sicily. Left-hand specimen is $V$. ciliata Dumort. Reproduced by kind permission of Museo di Storia Naturale dell'Università, Firenze, via Chiara Nepi. The lectotype label has been added to the image; it is not present on the FI sheet. 


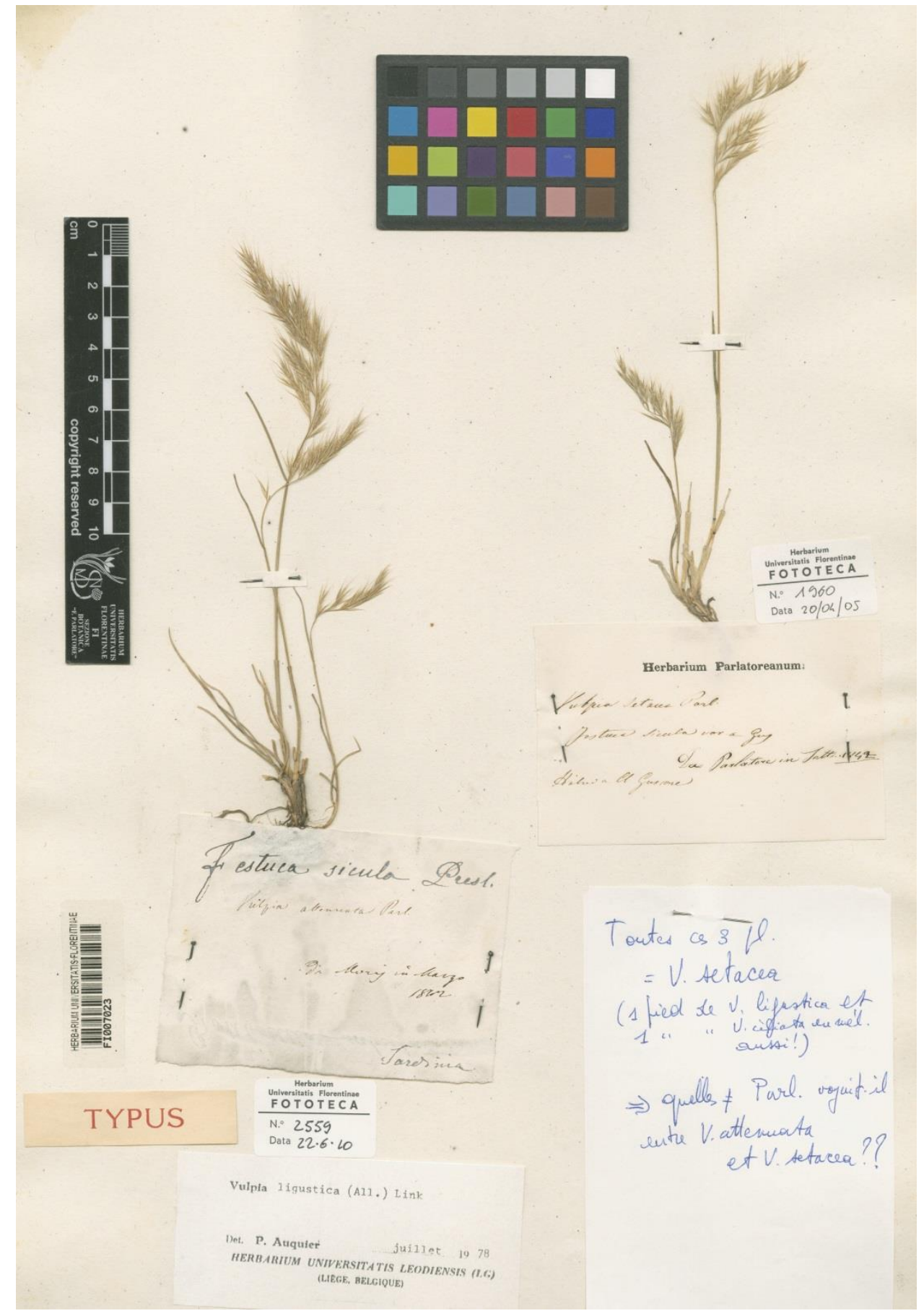

Figure 2. Sheet FI007023. Left-hand specimen is Vulpia sicula (C. Presl) Link, collected by G.G. Moris in Sardinia. Right-hand specimen is $V$. ligustica (All.) Link. Reproduced by kind permission of Museo di Storia Naturale dell'Università, Firenze, via Chiara Nepi. The unattributed label pinned to the bottom right of the sheet bears Paul Auquier's handwriting (fide C.A.S.). 
Copyright retained by author(s). Published by BSBI under the terms of the Creative Commons Attribution 4.0 International Public License.

ISSN: $2632-4970$

https://doi.org/10.33928/bib.2021.03.379 